\title{
Guidance and Counseling Services in Improving the Psychological Well- Being Young Prisoners
}

\author{
Akmil Rahmi ${ }^{1}$, Marjohan Marjohan ${ }^{2}$, Daharnis Daharnis ${ }^{3}$ \\ ${ }^{123}$ Universitas Negeri Padang, Padang - Indonesia, (akmilrahmii@gmail.com)
}

\begin{abstract}
Young prisoners need guidance, direction and assistance from parents and the immediate environment in order to develop into more mature. Some of the problems experienced by young prisoners are not able to accept themselves and difficult circumstances to direct behavior so that affects the psychological well-being. Psychological well-being is a condition in which an individual can accept themselves and be able to rise from its current state. This article discusses the basic concepts of psychological well-being and the importance of guidance and counseling services.
\end{abstract}

Keywords: young prisoners, guidance and counseling, psychological well-being

This is an open access article distributed under the Creative Commons 4.0 Attribution License, the which permits unrestricted use, distribution, and reproduction in any medium, Provided the original work is properly cited. (C) 2018 by author and Faculty of education, University of Padang.

\section{Introduction}

Adolescence is a transition period that marked by physical and psychological changes from childhood to adulthood (Hurlock, 1999; Nasution, 2007). Adolescence is also defined as a period of growth and development with the characteristics there are important changes in cognitive function, behavioral, social, and emotional appropriate biological development, as well as their functions and new demands on the family and social environment (Haryono,A., Rindiarti, A., Arianti, A., Pawitri, A., Ushuluddin, A., Setiawati, A., Reza, A., Wawolumaja, CW, \&Sekartini, R., 2016). Adolescence is also known as the age in question (Hurlock, 1999). Although every period has its own problems, problems of adolescence be a difficult problem to overcome (Gunarsa, 1991; Aziz, 1999). This is due to the lack of experience in dealing with the problem but to deal with it and refuses help from parents or other adults. Therefore, many adolescences solve problems that do not match their expectations. Lack of knowledge, state of mind that is still unstable, the faith which is lacking and there is no good communication within the family makes adolescence who have trouble escaping into things that are negative, even some involved in legal cases and should be jailed (Afrinisna,2013).

All prisoners, especially those classified as young prisoners need guidance, direction and mentoring of parents and the immediate environment so that they can develop more mature (Sarwono, 2011). However, its presence in the prison make young prisoners separate from their parents and have to live 
with other prisoners from different walks of life. Various problems faced by young prisoners in custody during and after finished serving his sentence. Masagutov and Anderson (2013) revealed that the young prisoners reported being susceptible to abused while in prison. Besides having problems in communication, interest in homosexuality, sexual aggression against other prisoners, low selfassessment, a suicide attempt, an attempt to escape from prison, aggressive fantasies and obsessive fear. Sexual offenders with low self-esteem are more likely to be recidivists (David Anthony \& William, 2004). Prison environment is also a source of trauma and stress, particularly among younger prisoners (Tina, Sandy, Christian \& Keith, 2011).

Currently, the number of children under age involved in crime is increasing. This relates to the everyday lifestyle of children and social pressures. Unlawful behavior, causing the youth criminal penalties penalized according to the type of cases that do. The influx of adolescence into the prison will cause a loss of freedom, difficulty in adjusting to, and feel lonely, which eventually will have an impact on the condition of psychological well-being. Young prisoners in correctional institutions will undergo a new adaptation to the environment, the first time you inhabit prisons.

\section{Discussion}

\section{Basic Concepts of Psychological Well-Being}

Psychological well-being is the psychological state of individuals who may receive state or condition itself, both the positives and negatives as well as positives can interpret every event or events that never happened. Psychological well-being as an encouragement to explore the potential of the individual as a whole. The impulse can cause someone to be resigned to the situation that makes the psychological wellbeing of individuals to be low or attempting to improve living conditions which will make the psychological well-being of the individual to be high (Ryff\& Keyes, 1995). Ryff (1989) explains that the psychological well-being is the full achievement of the potential psychological, where the individual can accept the strengths and weaknesses that exist in itself, create positive relationships with others who are nearby, has the ability to make decisions and be independent, able and competent to manage the environment, having a purpose in life and felt able to through the development of his life (Ryff, 1989).

Snyder and Lopez (in the Southeast, Zamralita\&Suyasa, 2008) revealed that the psychological wellbeing and not merely the absence of suffering, but the psychological well-being include attachments active in the world, to understand the meaning and purpose of life and the person's relationship to objects or others. Individuals who have psychological well-being positive are individuals who have a positive response to the dimensions of psychological well-being sustainable. In essence psychological well-being refers to a person's feelings about the activities of daily living. These feelings can range from mental conditions negatively, for example, dissatisfaction with life, anxiety, depressed, self-confidence is low, and often behave aggressively, to the mental state of positive, realization of potential and selfactualization (Bradburn in Liwarti, 2013).

Individuals with psychological well-being that both will have the ability to choose and create the environment in accordance with his physical condition. In other words, have the ability in the face of events beyond himself. In addition, individuals can also receive their own strengths and weaknesses as they are, have a positive relationship with other people and be able to direct their own behavior.

\section{Guidance and Counseling Services to Improve Psychological Well-Being Young Prisoners}

Especially young prisoners require both moral and material encouragement, affection and acceptance from their parents and their environment. In fact, it is not uncommon prisoners who actually shunned by 
her family as if it were left alone to face the problem. Henning V (2011) revealed that it is not uncommon for prisoners who experience anxiety, feeling disorders even symptoms of depression. This makes young prisoners feel excluded and feared to return to his neighborhood after the detention period is complete.

Life in correctional institutions was strictly limited by the rules of the institution, making prisoners difficulties in meeting the needs of such when they are outside the penitentiary. The life of young prisoners in a correctional institution is certainly different from the lives of friends his age who live outside prisons.

Accordingly, it can be understood that young prisoners should be given special treatment that aims to shape attitudes and behavior. It aims to give an opportunity to young prisoners to prepare to live independently and participate actively in the development of the community after undergoing free of punishment.

Various problems that arise in young prisoners to be a reference for counselors in implementing guidance and counseling services, especially in the personal aspect. Young prisoners need to be guided and nurtured through education, one counseling. Guidance and counseling services for young prisoners also be implemented as an effort to help young prisoners in improving psychological well-being.

Guidance and counseling provided refers to the seven areas of development, ten kinds of guidance and counseling services and six support activities. The objective of guidance and counseling services in question is (1) Service Orientation, which is to help people understand the new environment and make it easier to adapt to the individual when in a new environment; (2) Information Service, which is to help people accept and understand the broad range of knowledge related to the field of personal, social, learning, career/job and further education; (3) Placement and Distribution Service, which is to help individuals obtain proper placement and distribution in the various occupations/activities in accordance with the potential of the individual; (4) Content Control Service, which is to help individuals master the specific content, especially competence or habits that are useful in family and community life; (5) Individual Counseling Service, which is to help individuals to alleviate personal problems; (6) Guidance Services Group, which is to assist the individual in personal development, social relations, learning, career / job, and decision-making, as well as perform certain activities through group dynamics; (7) Counseling Services Group, which is to assist individuals in discussing or alleviate personal problems through group dynamics; (8) Consulting Services, which is to help individuals and/or other parties in gaining insight, understanding, and ways need to be implemented in handling the conditions and/or individual problems; (9) Mediation Services, which is to assist learners in solving the problems of passage and to improve relations between them during the conflict and (10) Service Advocacy, which is to help individuals to fulfill a range of rights that have been violated by people/organizations in the fulfillment (Erman A. \& Marjohan, 2008; Prayitno 2014; Afdal, 2015; Alizamar, 2016).

Guidance and counseling services provided in order to improve the psychological well-being of young prisoners, young prisoners who will be given an understanding of the psychological well-being, so as to apply them in everyday life. Based on the type of service that has been put forward, the special service, in addition to other appropriate services provided to young prisoners are (1) Information Services, are intended to assist young prisoners to get the necessary information for the desired plan with regard to psychological well-being. Through this service is expected to young prisoners acquire new knowledge and can apply it in everyday life; (2) Guidance Services and Counseling Group, aims for young prisoners can take advantage of the dynamics of the group to discuss a particular topic or issue related to psychological well-being. Through this service is expected to train young prisoners were able to build a good relationship with the members of the group and independent in expressing their opinions; 
(3) Individual Counseling Services, aims to assist young prisoners in alleviating the problems they are experiencing with regard to psychological well-being.

In the implementation, the implementation of the service in question requires cooperation from various parties. The counselor of a correctional institution is someone who interacts most with the young prisoners. Considering that it will be very effective if the counselor can interact and cooperate in providing optimal services to young prisoners (Satya, Syahniar \& Daharnis, 2014).

\section{Conclusions}

The above discussion shows the importance to improve the psychological well-being young prisoners. Psychological well-being will help the young prisoners in living their everyday lives. With their psychological well-being is good then young prisoners will try to improve his life. Conversely, due to lower psychological well-being so, young prisoners will be depressed and resigned to the situation. Young prisoners who own psychological well-being that is both expected to maintain and for young prisoners who do not, need to be given an understanding with the aim to improve the psychological wellbeing. Through the guidance and counseling services is expected to improve the state of psychological well-being of young prisoners, of course, this can be achieved with a good cooperation with relevant parties (parents and other parties coaching institutions).

\section{References}

Afdal, A. (2015). Kolaboratif Kerja Konselor Masa Depan. Jurnal Konseling dan Pendidikan, 3(2).

Afrinisna, R. Y. (2013). Penyebab dan Kondisi Psikologis Narapidana Kasus Narkoba Pada Remaja. Empathy Jurnal Fakultas Psikologi, 2(1).

Alizamar. (2016). Teori Belajar dan Pembelajaran (Implementasi dalam Bimbingan Kelompok Belajar di Perguruan Tinggi). Yogyakarta: Media Akademi.

Aziz, R. (1993). Hubungan Antara Kecerdasan Emosional Dengan Penyesuaian Diri Dan Kecenderungan Berperilaku Delikuen Pada Remaja (Doctoral dissertation, Tesis, Yogyakarta, Program Pasca Sarjana Psikologi UGM).

David T., Anthony B., \& William L. M. (2004). Pretreatment Self-Esteem and Posttreatment Sexual Recidivism. International Journal of Offender Therapy and Comparative Criminology.

Erman A. \& Marjohan.(2008). Bimbingan dan Konseling. Jakarta: Depdikbud.

Haryono, A., Rindiarti, A., Arianti, A., Pawitri, A., Ushuluddin, A., Setiawati, A., Reza, A., Wawolumaja, C. W., \& Sekartini, R. (2016). Prevalensi Gangguan Tidur Pada Remaja Usia 12-15 Tahun di Sekolah Lanjutan Tingkat Pertama. Sari Pediatri, 11(3).

Henning V. (2011). Depression, Anxiety, and History of Substance Abuse Among Norwegian Inmates in Preventive Detention: Reason to Worry?. BMC Psychiatry.

Hurlock, E.B. (1999). Psikologi Perkembangan: Suatu Pendekatan Sepanjang Rentang Kehidupan. (Istiwidayanti \& Soedjarwo, Ed.) Jakarta: Erlangga.

Gunarsa, S. D. (1991). Psikologi Praktis: Anak, Remaja dan Keluarga. BPK: Gunung Mulia.

Kartono, K. (2011). Patologi Sosial. Jakarta: Rajawali Press.

Liwarti. (2013). Hubungan Pengalaman Spiritual dengan Psychological Well Being Pada Penghuni Lembaga Permasyarakatan. Jurnal Sains dan Praktik Psikologi,1 (1). 
Masagutov and Peter B. A. (2003). Sexual Violence and Aggressive Behavior Among Teenage Boys In The General Population and In Juvenile Prison, In Russia: A Descriptive Analysis. The International Electronic Journal of Health Education.

Nasution, I. K. (2007). Stres Pada Remaja. USU Repository.

Prayitno. (2014). Seri Layanan dan Kegiatan Pendukung. Padang: PPK FIP UNP.

Ryff, C. D. (1989). Happiness is Everything, or is It? Explorations on The Meaning of Psychological WellBeing. Journal of Personality and Social Psychology, 57 (6).

Ryff, C. D. (2013). Psychological Well-Being Revisited: Advances in Science and Practice of Eudaimonia. Psychother Psychosom.

Ryff, C. D., \& Keyes, C. L. M. (1995). The Structure of Psychological Well-Being Revisited. Journal of Personality and Social Psychology, 69 (4).

Sarwono, S. W. (2011). Pengantar Psikologi Umum. Jakarta: PT. Raja Grafindo Persada.

Satya, A. P., Syahniar \& Dahanis. (2014). Pelaksanaan Layanan Bimbingan dan Konseling di Sekolah Menengah Atas Negeri (SMAN) 4 Kerinci. Konselor, 3(4).

Tenggara, H., Zamralita \& Suyasa, S. T. Y. S. (2008). Kepuasan Kerja dan Kesejahteraan Psikologis Karyawan. Jurnal Ilmiah Psikologi Industri dan Organisasi, 10.

Thimma K., Stephan H., Marie C. B., \& Dirk B. (2016). Violence in Youth Custody: Risk Factors of Violent Misconduct Among Inmates of German Young Offender Institutions. European Journal of Criminology.

Tina M., Sandy G., Kristen M. Z., \& Keith M. (2011). Trauma and Life Event Stressors Among Young and Older Adult Prisoners. Journal of Correctional Health Care. 